\title{
Hour Times Percent
}

National Cancer Institute

\section{Source}

National Cancer Institute. Hour Times Percent. NCI Thesaurus. Code C139131.

A unit of measure for the area under an effect curve (AUEC), defined as hours times

percent. 